\title{
Connecting to Global Production Networks: Challenges for Regional Actors in Northern Norway ${ }^{1}$
}

\author{
Trond Nilsen , \\ Northern Research Institute Norway, Tromsø, Norway \\ Stig Karlstad, \\ Northern Research Institute Norway, Tromsø, Norway
}

\begin{abstract}
Over the past few years, Northern Norway has been perceived as a land of opportunity. Announcements of offshore oil and gas discoveries off the coast of Finnmark have contributed to increased market activity in related sectors like service and construction. However, regional firms continue to score at the bottom of innovation indexes and seldom compete on international markets. Based on indepth interviews with representatives from key businesses in three sectors in Northern Norway, we examine the bottlenecks that have prevented these firms from gaining new market positions through the interplay of these regional firms and agencies with the Global Production Network (GPN). We adopt the concept of "strategic coupling" and explore whether an actor approach can contribute to an improved understanding of this relationship. The paper demonstrates that regional strategies and public policy differ between the sectors. Public policy is important for regional firms within the petroleum sector. However, the funds available for regional firms continue to be limited due to the size and relevance of the measures. In the construction sector, public policy instruments are important, but not sufficiently adapted to the challenges these firms face. While the petroleum sector receives support and backing from regional agencies in order to connect to GPN, the wind power sector is actively hindered by the same agencies. The former have the opportunity to take part in new regional path creation; the latter have experienced a lack of strategic cooperation and face the risk of reducing strategic couplings to GPN, leading to path dependent processes that lock these firms into traditional and low-tech sectors.
\end{abstract}

Keywords: path renewal; business development; path dependency; strategic couplings; public instruments

Received: October 2015; Accepted: March 2016; Published: May 2016

\section{Introduction}

The broad theme of regional path development has received increased interest in the fields of innovation studies and economic geography. Traditionally, research on

${ }^{\star}$ Correspondence to: Trond Nilsen, Northern Research Institute Norway, PB 6434, 9294 Tromsø, Norway. Email: trond@norut.no 
how new industries emerge and grow has been based on theory from evolutionary economic geography, where regional path development is attributed to endogenous forces in core areas of urban economies. The literature in this field focuses on assets for path development, where "thick" innovation systems dominate. Path dependent regional industrial development means that existing industries and institutional structures create a regional environment in which current activity continues, and new activity arises (Martin and Sunley, 2006). From such a perspective, regional industrial development is based on endogenous factors, where past economic development "sets the possibilities," and present development guides new opportunities. New industries in a region grow out of existing ones through branching processes (Boschma and Frenken, 2011) and through new firm formation developed by researchers and engineers working in the region (Feldman, 2007). Dense regional structures and endogenous development processes such as a large number of innovative firms in related industries, scientific excellence, and a combination of different knowledge bases will spawn and develop new industries (Isaksen and Trippl, 2014). All of these factors influence emerging regional innovation systems (Cooke et al., 1997; Asheim and Gertler, 2005).

Peripheral regions lack such preconditions, and are often specialized in traditional primary and subordinate economic activities. They have low or no levels of $\mathrm{R} \& \mathrm{D}$, score low on knowledge variety and innovation, and have thin structures of knowledge- and support institutions (Tödtling and Trippl, 2005). The literature suggests that key assets for the development of new endogenous industrial paths are lacking in peripheral regions (Isaksen and Trippl, 2014). These areas are often locked into paths dominated by traditional, low-tech, resource-based industries. It is argued that peripheral regions seldom develop specialized production systems because they lack essential inputs such as knowledge and capital (Amin and Thrift, 1992). However, recently we have seen growth in relatively specialized supplier clusters in Northern Norway as new firms have entered the region (Arbo and Hersoug, 2010; Eikeland et al., 2010; Nilsen et al., 2013; Eikeland and Nilsen, (forthcoming) 2016). Key drivers of this growth are enhanced industrial activity, growth in public budgets and the increasing globalization of the marine industry (Ministry of Petroleum and Energy (2010-2011). The stability of political institutions and regulations has increased opportunities for new entrepreneurs and innovation in this region. In the literature, the Global Production Network (GPN) approach has made a key contribution to the rethinking of regional development processes in relational terms (Coe et al., 2004). Specifically, the GPN-approach successfully incorporates exogenous processes that have been neglected by the literature on regional development since the 1990's. The Northern Norwegian regional firms we studied first encountered multinational corporations (MNCs) from a starting point where the regional firms scored at the bottom of innovation indexes (Research Council, 2015), used few resources on research and development (R\&D) and seldom competed on international markets. The gap between increasing market opportunities as a result of enhanced interest from multinational corporations, and a lack of endogenous capacity to serve these demands inside the region in terms of businesses, is the 
empirical starting point of this paper. As regional policy has been neglected in most of the GPN-literature so far, we address challenges for regional firms' further growth and explore how the interplay with regional policy relates to their coupling to GPN. In highlighting and discussing processes of developing endogenous capacity for local and regional assets, we apply a perspective of local and regional agency to highlight how regional actors adapt to regional change.

Stimulating path development is a goal in regional innovation policies, and includes path extension, renewal and creation. The interplay between firms and regional innovation policies, especially regarding public funding, raises the question of the role of agency in regional development. A perspective that deals with this issue is the concept of strategic coupling, which refers to the process of matching local assets with global network demands (MacKinnon, 2011). Recent studies link the perspective of agency at the regional level to the concept of strategic coupling, and highlight that strategic coupling does not occur automatically as a result of the agglomeration of economies located in one place, but is driven and initiated by pro-active regional actors pursuing strategic action (Jacobs and Lagendijk, 2014). Consequently, the role of regional agency is seen as a critical mechanism in regional development, and is important to an understanding of how regions adapt to change. In this paper, we apply the concept of strategic coupling in line with Jacobs and Lagendijk's approach, and address the following research question, "What are the main challenges that regional firms in Northern Norway confront in their strategic efforts to couple with GPN in the petroleum, wind power, and construction sectors?"

The paper is organized as follows: We start with a theoretical discussion of the notion of path dependence and discuss whether the concept of endogenous versus exogenous sources of development has the potential to increase our understanding of the interplay between firms and public bodies like funding institutions. The concept of Global Production Network and "strategic coupling" is pivotal because the starting point of this perspective leans on the idea of exogenous impulses as drivers of growth in peripheral regions. The empirical section highlights the role of regional firms in connecting to GPN and discusses in detail bottlenecks for further growth, including the interplay with public actors to solve these challenges. Finally, the concluding remarks discuss the implications of the empirical findings for theories on regional development.

\section{Path dependency development}

\subsection{Endogenous growth}

Over the last few years, research in the field of economic geography has increasingly focused on evolutionary processes (Grabher, 2009). The theory is that experienced competencies developed over time by entities in certain localities regulate both present and future developments (Kogler, 2015). In short, history matters in shaping the contemporary socio-economic landscape. In line with such thinking, the notion of path dependent regional industrial development focuses on the "negative and 
positive lock-in effects that push a technology, an industry, or a regional economy along one path rather than another" (Narula, 2002). As such, path dependence means that regional industries enter into path extension primarily through incremental product process innovations in existing industries and technological paths. Regarding growth in a regional economy, path dependence implies that local and regional firms increase their market position, generate more jobs and contribute to development through continuity or more of the same in the regional economy. In such a situation, regional industries may eventually experience stagnation and gradual decline due to a lack of renewal (Hassink, 2010). Regional firms risk path exhaustion, which refers to a situation where the innovation potential of local and regional firms is reduced, or innovation only takes place along a restricted technological path. This situation reflects more or less high connectivity between regional firms and actors, but few links to extra-regional firms or the outside world. This lock-in situation may eventually result in exhaustion.

Recent theoretical contributions to evolutionary economic geography have supplemented notions of path dependent processes that focus on continuity and lock-in, with alternative and more dynamic paths. They suggest that changes may follow from different re-organization processes of industries in a region (MacKinnon et al., 2009). Path renewal occurs when local businesses shift into new or related activities. Consequently, path renewal is often developed within the industry as a regional industry broadens its industrial structure into new or related areas of expertise (Boschma and Frenken, 2011). Path creation represents a more radical change in a regional economy, and includes the formation of new firms and new sectors. Consequently, path creation means that existing regional businesses may develop new products, apply new techniques and technology, and create a new organizational structures (Martin and Sunley, 2006).

\subsection{Exogenous sources of path dependent development}

One should be cautious about using the same explanatory models to understand innovation and growth processes in peripheral and urban regions (Isaksen and Trippl, 2014). Studies of new industrial paths in peripheral regions point to the vital role of exogenous development impulses such as the arrival of innovative firms from outside and other forms of inflow of external knowledge (Leibovitz, 2004; Rees, 2005; Isaksen and Trippl, 2014; Eikeland and Nilsen, forthcoming, 2016). Key sources of new path creation are radical new technologies, industries, firms or institutional arrangements from outside (Martin and Sunley, 2006). Compared to the literature on core regions and knowledge bases, local knowledge sources appear to be relatively less important for firms located in lower-order regions. While firms in core regions cooperate with universities on innovation, firms in lower-order regions consider universities mainly as suppliers of a skilled workforce.

Deriving from this, findings from a comparative study of two sectors in the ICT and software industry in Austria and Norway show that the exogenous development impulse in the form of the inflow of new analytical and synthetic knowledge comes from outside initiated new paths (Isaksen and Trippl, 2014). They found that 


\section{T. Nilsen and S. Karlstad}

policy-makers and other key actors play a pivotal role in creating and sustaining new industrial activities in the periphery. Sanches (1992) argues that the main stimulation of new path development in peripheral regions is efforts by regional or national governments to attract external investments. However, these conceptualizations of regional path development give no attention to the role of the state (MacKinnon et al., 2009). Thus, there is little insight available into the scope for policy-supported path creation (Morgan, 2013). It is argued that analyses of new path development in peripheral regions, in particular, should take into account the role of policy actors and interventions on multiple scales (Dawley, 2014). Research on regional path development tends to neglect the role of policy interventions in new path creation (MacKinnon et al., 2009; Martin, 2012; Simmie, 2012; Morgan, 2013; Dawley, 2014).

The Global Production Network perspective explores the organization of global industries and how they are governed. A GPN refers to "(...) the globally organized nexus of interconnected functions and operations by firms and non-firm institutions through which goods and services are produced and distributed" (Coe et al., 2004:471). The use of network tolerates a more open and fluid understanding of production, involving many relevant actors and networks (Henderson et al., 2002). The GPN approach underlines three elements in its theorization. First, value, meaning economic return, and the rent generated by the production of commodities, involving the translation of labor power into actual labor process (Henderson et al., 2002). Second, power, understood as a practice in terms of the capacity to exercise power, including: the corporate power of the principal firm in GPN to influence decisions; the institutional power of national and local states; and the collective power of collective actors and trade unions (Allen, 2003). Third, societal embeddedness, network embeddedness and territorial embeddedness, which deals with the degree to which GPNs are anchored in regions.

Consequently, regional change is a result of the strategic coupling between GPNs and regional assets (MacKinnon, 2011:230). In line with Yeung (2009), strategic coupling means the processes where actors in regions coordinate and facilitate strategic interests between regional agencies and their counterparts globally. The role of regional agency is to ensure that such strategic coupling occurs by influencing regional assets to fit the necessities of lead firms in GPN. Coe et al. (2004) argues that this rests upon the creation, capture and enrichment of value. Value creation involves the formation of supporting conditions for development by regional institutions, including: training, education programs and promoting start-ups. Enhancement of value refers to upgrading industrial skills, technological transfer, delivery of better infrastructure and enhancement of specialized skills (Coe et al., 2004). Finally, value capture involves processes that anchor key firms to a region.

Jacobs and Lagendijk (2014) connect the perspective of agency at the regional level with the concept of strategic coupling in a recent study. In studying the containerized transport system in Rotterdam, they argue that strategic coupling does not happen automatically as a result of agglomeration economies located in one place, but are driven and initiated by pro-active actors regionally that pursue strategic 
action (Jacobs and Lagendijk, 2014:49). This includes public bodies and business agents trying to enhance the business environment to attract firms and boost the regional economy. Accordingly, they ask - what is the role of agents, local and global, public and private, in strategic coupling? Answering this question depends on the spatial location and interests of the agents involved. Jacobs and Lagendijk argue that it is the drivers and strategies of agents as they engage in strategic coupling that is central to an understanding of the formation of strategic coupling between actors and systems at different geographic levels. Consequently, the role of regional agency is approached as a pivotal mechanism in regional development from this point of view, and important in understanding how regions adapt to change.

\section{Northern Norway - a sparsely populated region}

The region of Northern Norway is sparsely populated and has only two cities (Tromsø and Bodø) with over 35,000 inhabitants. Consequently, the region is peripheral. It has specific peripheral characteristics, and has historically been a disadvantaged area economically. Finnmark is the largest and least populous of the northern counties in Norway, with 74,000 inhabitants spread across $46,000 \mathrm{~km}^{2}$. The long and narrow shape of the region of Northern Norway creates long internal distances and related climatic, economic and cultural differences (Fitjar, 2013). When it comes to economic development, the region of Northern Norway, and Finnmark especially, is among Norway's weakest, and has been a target region for regional policy. Accordingly, a range of policy mechanisms have been implemented to attract capital and skilled labor to the region. A recent study argues that according to selfimage, the region has remained poor despite being rich in natural resources (Fitjar, 2013). The reason for this is mainly that resources are extracted and developed in economic centers farther south in Norway. Hence, it is relevant to focus on the role of growth policy because Northern Norway has evident peripheral characteristics, with few endogenous dynamics.

The public funding system is an important actor in the Regional Innovation Systems (RIS) in Norway, and consists of several agencies, like Innovation Norway, SIVA, the Research Council of Norway, and county governments. ${ }^{2}$ The first three contribute to the financing of projects within companies and to industry actors aimed at enhancing innovation and infrastructure. The counties do not manage their own business-related funds, but provide financial support for business parks, business incubators, and cluster organizations. A discussion on the function and operation of the public instrument systems can be considered from three perspectives (Halvorsen, 2002), reflecting three theoretical directions in economics. In Norway, supporters of John Maynard Keynes' three principal tenets dominated ideology in the period 1950-1970. Most of the present-day public instrument system was established during this period. The thinking was founded on the belief in public governance and the regulation of demand. Later, the management of public policy systems and funding systems in Norway was oriented towards the neoclassical economists' school of thought. The central thinking is that the free market is the most effective 


\section{T. Nilsen and S. Karlstad}

instrument for allocating resources (Halvorsen, 2002). Belief in the market has led followers of this school to argue either for very general instruments or for no instruments at all. More recently, the 1990s witnessed a development among professionals in which new theoretical ideas emerged, and since then concepts of endogenous growth, learning regions, regional innovation systems, clusters, and networks have risen higher on the agenda.

\section{Methods and data}

Our study was conducted in 2013 and 2014, with interviews spread between these two years. This article is based on data from businesses' experiences of their activities in Northern Norway. The data comprises three parts. As the businesses in the region are our main unit of analysis, 35 structural interviews were conducted with representatives from central businesses in industrial sectors, including construction (6), renewable energy (10), petroleum (12), maritime activities (3), and research and development (R\&D) (4). The material included small and medium-sized enterprises and international corporations headquartered in other parts of Norway and in Europe. The interviews were conducted by telephone and "face-to face" meetings with informants. Some interviews were tape-recorded and the recordings were later transcribed, while other interviews were documented by note-taking during the conversations. The second part of the data comprises written material like reports, regional planning documents and public documents from accessible sources. The third part is based on our experience and knowledge acquired through direct involvement in academic research related to industry. The data from the interviews was sorted, interpreted and analyzed with respect to the research question stated in section one of this paper.

\section{Challenges facing actors in the three sectors}

\subsection{Petroleumindustry - regional firms and MNCs}

The petroleum industry entered the Northern Norway region in 1997. Local actors lobbying facilitated the embedding of this sector in Northern Norway (Nilsen, 2008). The encounter between a GPN in the oil industry and a peripheral region is characterized by imported technology to the region, and a striking imbalance between the existing business structure and population and the oil companies' operations. This imbalance is reflected in Finnmark and Nordland where companies like Statoil, BP and Eni Norway are the main actors followed by global contractors like Aibel, Bilfinger, Subsea7, Aker Solution, Haliburtion and Apply. However, recent studies have documented that firms from the region have loosened their grip on the local context and coupled with the GPN system of global oil service firms (Eikeland, 2014). The companies in the GPN have pursued strategies to avoid the potential politically tense situation of not leaving anything behind for the region through intricate forms of networking and negotiation (Nilsen, 2008). They have built regional alliances of a strategic nature by distributing small contracts to regional 
firms and supporting local initiatives (Arbo and Hersoug, 2010; Eikeland, 2014). One strategy of the oil companies has been to get involved in local alliances, supporting education, business development and the upgrading regional skills. The oil companies have gained political momentum through their support of local industries in Hammerfest, Tromsø, Harstad and Sandnessiøen. This experience reflects that "global" players gain more from being active players in local development, than from being passive (Jacobs and Lagendijk, 2014). This is especially the case in the context of the Barents Sea, because of the growth potential of this peripheral area for new petroleum development in the years to come. Thus, being a responsible corporate actor in this context is imperative to the companies, as this may lead to political goodwill both with regard to the local communities, regional agencies and national political agencies.

MNCs need to invest in and be willing to partake in local alliances for political reasons. Regional firms have a shared interest in participating in alliances with the aim of improving their own market position and enhancing value creation. Being located 2000 kilometers away from the dominating clusters in the oil and gas industry, essentially creates opportunities for local firms and agencies, as MNCs have a business interest themselves in joining forces to develop strategic coupling between themselves and local actors. The need for services and products in proximity to sites is important for the MNCs for both economic and safety reasons, because proximity reduces response times in emergency situations or if services must be supplied, compared to a strategy of fly-in/fly-out from other geographical locations. Thus, there has been a strong willingness on the part of the MNCs to locate engineering activities and administrative services within the region. The entering industrial sectors impact other sectors as they demand sub-contractors, improving the income of the municipalities through tax income and boosting the regional economy. This has a connection to path creation as this is a new industry for the region, which in turn has stimulated the development of new economic patterns.

One of the challenges regional firms identified was how to develop strategies to become even more competitive. Regional policies have supported the firms with their available measures, promoted the region, facilitated enhanced education processes and supported the development of infrastructure. ${ }^{3}$ As a result, regional firms have developed strategies to develop competence and participate in supplier programmes and improve health, security and quality (HSQ), all of which have been enabling strategies in their efforts to connect to GPN. However, the overall output of these strategies has seen only modest success. A few local and regional firms have connected to GPN, but many of the firms in the region have been "closed out of competition" because of established agreements between contractors and main suppliers. The use of frame agreements is one example of this. Another challenge has been to adapt to the contractual system used by the industry and to become competitive within the framework of contractual strategy with large contracts. Further, a lack of skilled local labor has been a challenge for local firms and their capacity to take on new assignments. Finally, firms have increased their competitiveness outside the oil and gas sector, especially within construction and renewable energy. 


\section{T. Nilsen and S. Karlstad}

MNCs in the maintenance and modification segment reported that the challenge regarding human capital concerned finding local personnel "who are good enough." As a result, commuting costs for operating companies are relatively high. From a market perspective, this might not be perceived as a relevant issue, since expertise can be brought in from all parts of the world. However, local labor is relevant not only with regard to savings on commuting costs, but also to formal requirements regarding the employment of local workers as part of subcontractors' workforces in the petroleum industry (Nilssen et al., 2012). The interviewed representatives from Statoil, which has cut the transportation costs of their suppliers' personnel when formulating maintenance and modification contracts, confirm this argument.

As the sector largely consists of MNCs, using public instruments to fund development projects is seldom a topic within the petroleum industry. For this particular industry, MNCs report that concessions of various types, public demand and tax arrangements are far more important and relevant instruments. Of the local firms within this sector, only one had utilized public support to create a viable start-up of a locally owned oil spill contingency firm, reflecting that regional firms have no strategy to seek funding.

\subsection{Renewable energy production - wind power}

The green energy wind sector in Northern Norway consists of a mix between locally owned firms (Finnmark Kraft, Varanger Kraft) and MNCs (Fred Olsen Renewables). Wind power is a relatively new sector for the region. Wind power is a challenge as Norway is self-sufficient from hydropower at a low cost because of already established infrastructure and natural geographical conditions with it numerous waterfalls. To be competitive a power source needs to be economically beneficial to society, require low investments and must be sustainably balanced with regard to state regulations, environmental considerations, and other businesses and traditions in Norwegian society.

Statoil and the Norwegian Research Council aimed to increase offshore-based wind power production (Research Council, 2011), largely based on the conclusions of a report from the European Wind Energy Association (EWEA, 2007). These recommendations were also encouraged and supported by Innovation Norway, the Research Council and the government during the economic crisis of 2008 (Eikeland, 2013). In 2008, an independent group of Norwegian experts on wind power also recommended increasing the role of offshore wind in Norway. Until recently, companies like Statoil, Statkraft and Statnett have viewed offshore wind power production as a new and upcoming renewable energy source because of favorable wind resources, available offshore locations with few land-based conflicts or visible concerns. ${ }^{4}$ Supported by the government through the Ministry of Petroleum and Energy, and the Research Council in Norway, offshore wind was adopted as a national strategy during 2000s. While the stable wind resources offshore and lack of conflicting interests enabled a positive attitude towards this strategy, investment and maintenance costs remain prohibitively high. 
The emergence of new wind power production in the peripheral region of Finnmark has been heatedly debated for several years. The first of four wind parks located in Northern Norway has produced power since 2002, and two more are under development. As the region has favorable conditions of steady wind resources throughout the whole year, huge areas without much infrastructure, an advantageous topography and the notion of a clean and green environment, the conditions for new wind production in the area are promising. The enhanced debate on climate change and the need for renewable energy sources add to the potential for this new regional path. International actors are also interested in the region because of its wind resources. ${ }^{5}$ However, counter-initiatives mobilizing to preserve nature and indigenous peoples' rights are gaining strong momentum. In recent years, the national government has rejected several new wind projects. Three hegemonic positions framing the overall concerns of new wind and renewable production have been identified to clarify these processes. These are (i) international and national proindustry and renewable energy (ii) the indigenous Saami discourse on land preservation and, (iii) regional entrepreneurial pro-wind arguments on self-sufficiency and energy export through new grid transmission.

First, linked to the debate on reducing emissions from fossil fuel energy sources, the international environment and national government aim at developing more renewable energy in the long term. At the national level, these aims are reflected in an official report conducted by the Ministry of Petroleum and Energy. ${ }^{6}$ Nevertheless, aims to increase wind energy production in Norway lack support from binding policy documents. The last White paper on energy in broad was published in 2006, and the expected new White paper has still not been published. ${ }^{7}$ In Norway in 2014 , wind power covered the electricity needs of 80,000 houses, equivalent to the city of Tromsø. The debate on improving wind as a new source of energy has not resulted in a significant volume of new wind power parks. Second, interview data confirms that local people in Northern Norway who use the land as an arena for business activities are mainly negative towards an active and progressive wind power extension. The most prominent voice of opposition comes from the indigenous Saami people, who actively opposite the development of wind power, arguing for their rights to land preservation and reindeer herding. Reindeer herding is the cultural and social fundament of the Saami population. The plans of both regional and MNC wind companies to invest in wind parks on land are in conflict with the Saami people and their reindeer herding. The political situation in the region regarding preservation versus commercialization is tense. The formal position of the Saami people in the region is quite adamant. Consequently, the Norwegian Water Resources and Energy Directorate $(\mathrm{NVE})^{8}$ have rejected several wind power proposals submitted by the locally-owned wind company Finnmark Kraft and other companies. In their rejection of the new wind parks, NVE refers to the Saami reindeer herding traditions and conflicts over land use, including, among others, Fallerascca and Ulveryggen in Kvalsund municipality.

Finally, the regional entrepreneurial pro-wind strategies fronted by regional actors concerning wind power as an opportunity for regional development and energy self- 


\section{T. Nilsen and S. Karlstad}

sufficiency include the possibility of energy export. ${ }^{9}$ In terms of regional development, the absence of expertise in the wind industry in Norway, such developments could only be undertaken in cooperation with MNCs and foreign suppliers that test and modify equipment to adapt it to the demanding nature and climatic conditions of the Arctic, including wind speeds, turbulence, humidity, and wind direction. Investors in the north, typically established hydropower companies, collaborate with national investors in the wind power industry when applications are submitted for permits to establish new wind parks. Access to capital is a critical factor because Norwegian banks require $50 \%$ equity to finance fully developed wind power projects.

Wind power is dependent on instruments such as "green" electricity certificates and $\mathrm{CO}_{2}$ taxes on polluting energy. Previously, financial support for wind power investments in Norway was granted by Enova, but this is no longer the case. Actors in the wind power sector claim that time-consuming licensing procedures and a lack of network capacity slows the development of wind power, partly due the lack of an electricity grid to export generated electricity and to import electricity when the level of wind power production is low. From the wind companies, it was stated that the dialogue with the environmental department in Northern Norway is time consuming and involves lengthy negotiations. Similar to FeFo's responsibilities concerning concessions and compensation for landowners, ${ }^{10}$ Finnmark County prepared a regional plan for wind power in 2012, but the wind power sector lacked sufficient involvement from the county for the realization of specific projects. With regard to governmental $\mathrm{R} \& \mathrm{D}$ instruments, regional actors in wind power report that funds need to be more business oriented and that existing programs disregard businesses' everyday needs.

\subsection{The construction industry - infrastructure and human capital}

The petroleum and wind power sectors are largely directed towards the global and national markets, while the construction industry is primarily engaged with local and regional markets. The construction sector in Norway comprises 75,000 firms and 340,000 employees. ${ }^{11}$ The sector is characterized by small firms; 97 percent have 20 employees or less. ${ }^{12}$ The largest companies are located in southern part of Norway and have subsidiaries in Northern Norway. In Finnmark, the Alta region has a large number of locally owned construction firms that have improved their market position as a result of the growth in oil and gas industry and related industries, as well as enhanced activity in new infrastructure in the region.

Local and regional firms have, as mentioned above, been successfully coupled with MNCs' activities in the region's petroleum sector. From the beginning of the 2000s, activity in connection with the Snøhvir field development onshore in Hammerfest created new market shares for these firms. As several of the firms were located in the municipality, they were connected to GPN through the geographical proximity to MNCs. Firms in both Alta and Hammerfest took relatively large market shares of the field development during the construction period, and firms within the construction period actually represented most of the NOK 2.8 billion supplies from the region to the field development of Snøhvit. Even though the petroleum sector has created 
opportunities for these firms, the regional firms mainly compete on the local and regional markets. In periods with few market opportunities locally, these firms participate in construction processes far away from their main location. Large distances between building sites and headquarters represent a challenge. Shipping freight over distances of $600-700 \mathrm{~km}$ from the center of Nordland County to the south of Finnmark require considerable outlays. Due to transportation costs for offshore freight, which is always higher than for road freight transported on trucks, this implies that heavy transport on roads will increase, with the accompanying risks that this entails. However, many projects were not realized due to limited access to capital in Northern Norway: "Unless banks are there and finance our developers, we'll never have our building frameworks or shells delivered. Capital is thus very important." 13

One example that highlights that research initiatives can alleviate challenges in the Arctic relates to the current ColdTech project, a sustainable cold climate technology initiative, carried out by the R\&D community in Narvik. Measurements of ice pressure on dams are taken from sensors at various depths in the ice with the aim of optimizing the dimensions and operational costs of dams. The project will also develop more effective ways of working with groundworks by mastering the cold, which could extend the season for construction workers. Another challenge faced by firms in the region is human capital and expertise. Both expertise in engineering and skilled concrete workers are scarce resources. The businesses are able to attract the right people if they are willing to pay for them. The following quote reveals one example of solutions used by the construction industry to recruit highly skilled labor:

We currently have over 50 employees, and the proportion from Sweden and Eastern Europe is increasing rapidly. They work 12 days on, 9 days off. In other words. If we were to stop doing this, we would have to scale down the workforce. ${ }^{14}$

Table 1 summarizes interview data from regional firms and MNCs' challenges distributed across industrial sectors.

Table 1. Summary of regional firms and MNCs' challenges distributed across industrial sectors

\begin{tabular}{lll}
\hline \multirow{2}{*}{$\begin{array}{l}\text { Industry } \\
\text { sector }\end{array}$} & \multicolumn{1}{c}{ Focused topics in MNCs } & \multicolumn{1}{c}{ Challenges } \\
\cline { 2 - 3 } Petroleum & $\begin{array}{l}\text { Infrastructure, access to concessions, hard to } \\
\text { recruit qualified and experienced labor }\end{array}$ & $\begin{array}{l}\text { Access to markets, experienced labor, access to } \\
\text { main contractors, avoiding frame agreements } \\
\text { Wind power }\end{array}$ \\
$\begin{array}{l}\text { Local resistance, the role of indigenous } \\
\text { people }\end{array}$ & $\begin{array}{l}\text { Saami people and land use, few regional } \\
\text { initiatives, lack of interest from public actors }\end{array}$ \\
Construction & $\begin{array}{l}\text { Large geographical distances within the } \\
\text { region, lack of qualified labor }\end{array}$ & $\begin{array}{l}\text { Large distances, winter, snow, lack of interest } \\
\text { from public bodies, lack of understanding from } \\
\text { public agencies }\end{array}$ \\
\end{tabular}




\section{Managing external relations at different geographical scales}

Rather than focusing on territorially bound contexts, the discussion in section five documents that a primary challenge for regional firms is to improve their connection to GPN. Consequently, a relational understanding of firms and their strategies to manage external relationships has been emphasized. Actors in different industrial sectors manage their external relations on different geographical levels, with the petroleum sector being primarily globally oriented and the construction sector being mostly connected to local and regional markets. As regional agencies and firms within the petroleum sector negotiate and take part in processes with mostly globally oriented firms, they encounter processes and requirements that are different from the context they are used to. It is evident that regional firms in a peripheral regions struggle to be competitive in new, global sectors in the region. The lobbying from regional agencies like the municipality of Hammerfest, Finnmark county and the supplier organization Petro Arctic involved other geographical levels than the regional. Most of the lobbying efforts to secure regional firms' access to the GPN were conducted at the national legislative level in Norway, and regulated MNCs through license concessions.

Consequently, regional actors seek inclusion in GPN through the help of national support through legislative processes and legally binding documents. In parallel, the wind power companies have their own lobby organizations, Norwea and Energy Norway, to promote their strategic interests. So far, these organizations have not succeeded in their efforts to promote wind power companies' interests in Finnmark. The context of Finnmark is unique as the indigenous Saami people have a strong political role and position in questions of land use in areas where reindeers are present. The fact that the question of concessions relates more to the needs of indigenous people and their traditional ways of living than to the interest of enhancing renewable energy towards a greening of electricity production, actually limits the role of external relationships and facilitators. On the other hand, the position of the Saami people in discussions of land use and new business activity is a politically tense issue. Accordingly, balancing the interests of wind companies and the new greening of electricity production in this context reflects historical, cultural and political tensions that go back several decades. Consequently, endogenous processes in the region and the need for balancing the different stakes and interests are crucial if new regional paths in renewable energy shall emerge within the wind power sector.

The construction sector is highly dependent on the market situation in related sectors. Evidence from our interviews indicates that managing external relations in the petroleum sector or the renewable sector, strongly influence developments in the construction sector. Businesses have received support from regional agencies, like transport-related support to compensate for the long distances involved. However, funding received does not correspond to the businesses' needs. Businesses have also received funding from local and regional bodies to develop more effective production systems. Business representatives report that the majority of useful instruments were obtained from a member organization of northern Norwegian contractors. The 
relevant support came from the industry itself and not from the public support system. These instruments had relevance and accuracy for the development of technology, internal training, and various measures relating to development contracts.

\section{Concluding remarks}

This paper has explored the most important challenges regional businesses must overcome in the petroleum, wind power, and construction sectors in order to improve their market positions, and thus become more closely linked to and integrated with GPN. Further, the paper has investigated the role and interplay with public instruments, specifically grants, in solving these challenges. The contribution of this paper has been to increase knowledge on the interplay between firms and regional policy and the role of agencies within the literature on GPN, a topic that has been more or less neglected so far. When new sectors enter a peripheral region with the potential to create new paths in regional development and industry, the combination of limitations in regional resources from regional agencies like public sector instruments, and the different actor strategies within the region, is striking. In general, regional petroleum firms have been supported by an active regional policy, facilitating regional support, promoting the region for MNCs, funding start-ups and supporting infrastructure. The joint strategic efforts of regional agencies in planning and facilitating support has been hindered by a lack of relevant regional resources to fund firms. At the same time, mutual interest in the MNCs have facilitated the strategic coupling of local firms to GPN in the petroleum sector, as the MNCs' strategic interest to create and maintain a good relationship with the government and municipalities, has commonalities with regional firms' interest in increasing their competitive position. This has created new paths for Hammerfest, building a foundation of path creation as the region has become more and more connected to GPN. The municipality of Hammerfest has 30-40 oil service firms today, compared to only two in 2001.

As documented in this paper, challenges facing the wind power sector in Finnmark are mainly related to the different strategies of the regional actors in Finnmark. The national strategy to increase the level of wind power has not been very successful, due to the fact that wind is still a minor power producer in Northern Norway. In addition, the Norwegian industry and research environment have been oriented towards offshore wind. At the local and regional level, the notion of land use and the rights of the Saami people have prevented large-scale wind power development. These two processes together hinder the building of new paths within the renewable sector, as the challenges pointed out by the firms in this study are mainly related to these factors. So far, the role of regional policy and agency in the region, do not seem to have succeeded in their efforts to loosen up the situation, even though the regional county level supports an active wind policy. The fact that Japanese $\mathrm{e}^{15}$ interests are eager to develop new wind power in the region, illustrates that the deadlocked situation continues to prevent the construction of new paths in the region, and thus lock-in, eventually path extension seems to be the most relevant pattern. Finally, the construction sector seems to follow the same pattern. This paper shows that this 


\section{T. Nilsen and S. Karlstad}

sector is tightly connected and dependent on the level of activity in the other sectors, such as transport (infrastructure) and oil and gas. A declining market situation in these sectors will reduce the market for construction firms, and vice versa when market situation in the other sectors is growing. While regional wind power agencies have conflicting interests regarding new developments in the sector, regional agencies within the petroleum sector have joined forces and cooperate with the aim to connect to GPN. The institutional backing of these two industrial sectors differs significantly.

As several firms report a lack of communication and strategic cooperation with regional funds and actors, one must be aware that this can diminish the strategic couplings of these firms to GPN, thus pointing to a strong degree of path dependence in the relationship between regions and GPN. Lock-in into traditional and low-tech sectors may occur and thus hinder the development of new and extended paths in the region. Still, most of the growth in the region the last few years has been embedded within the context of entering MNCs and their actions to increase market activity in Northern Norway. Highlighting growth processes related to construction, petroleum and partly the renewable sectors in Northern Norway, documents the need to balance theories that focus on endogenous sources of growth in evolutionary economic geography, with exogenous sources to new path development in peripheral areas. The concept of "strategic coupling" suggests that introducing a relational understanding of managing the external relationship between global production systems from outside and the regional assets within a specific geographic area, making it possible to highlight the growth process in itself, and the strength and content of relationships between firms and non-firms in a region. It highlights the dynamic processes by which relational assets are matched to the needs of GPN, with regional institutions playing a key role in this process.

To conclude, the analysis in this paper has demonstrated that the output of the coupling processes between regional firms and GPN differs. Strategic couplings within the petroleum sector have been successful and represent an asset to local economic development processes in the periphery, while the case of wind power illustrates that potential development processes are undone. Several factors hinder strategic couplings between regional actors and GPN, partly due to different strategies from national and regional actors and partly due to conflicting interests within the region. Finally, the construction sector is mainly concentrated on local and regional markets. Thus, the different mechanisms for growth within the sector represent a complex network of actors and are dependent on public and private investments connected with GPN.

\section{ACKNOWLEDGEMENTS}

The Norwegian Research Council supported this work through the research projects Technology Transfer, Technology-Based Entrepreneurship and Innovation (grant no. 247093) and Effects of Petroleum Investments in the Arctic Frontier (grant no. 237691/E30) 


\section{NOTES}

1. Sections of the empirical material here were previously published in the Norwegian journal KartEPlan, 2014/3, for a Norwegian audience.

2. In addition, other instruments originate from, for example, the higher education sector.

3. See i.e Regional Petroleum Strategies 2006-2009, by The Finnmark County Municipality http://docplayer.no/2042238-Petroleumsstrategier-for-finnmark-2006-2009.html

4. http://www.energinorge.no/getfile.php/FILER/NYHETER/ENERGIPRODUKSJON/Energir $\%$ C3\%83\%C2\%A5det $\% 20$ Vindkraft $\% 20$ offshore\%20presentasjon $\% 20260508$.pdf

5. http://www.norwea.no/nyhetsarkiv/visning-nyheter/japan-vil-ha-energi-fra-finnmark.aspx? $\mathrm{PID}=1145 \&$ Action $=1$

6. https://www.regjeringen.no/contentassets/eb90bf50e63b4df7ae472b75a1d4a71 c/no/pdfs/ nou201220120009000dddpdfs.pdf

7. https://www.regjeringen.no/no/dokumenter/nou-2012-9/id674092/?ch=1\&q=

8. NVE's mandate is to ensure an integrated and environmentally sound management of the country's water resources, promote efficient energy markets and cost-effective energy systems and contribute to efficient energy use, and is a directorate under the Ministry of Petroleum and Energy. https://www.nve.no/english/

9. Two central documents reflects these strategies. The first is the Finnmark County Municipality wind Plan, http://www.ffk.no/Handlers/fh.ashx?MId1=11523\&FilId=24567 and the second is the plan for regional development (RUP), http://www.ffk.no/Handlers/fh. ashx?MId $1=11523 \&$ Filld $=25265$

10. Under the Finnmark Act of 2005, FeFo (Finnmarks eiendommen ('the Finnmark Estate')) owns $96 \%$ of the area in Finnmark (Finnmarksloven 2005). FeFo is mandated to manage the land and natural resources in Finnmark in a sustainable manner for the benefit of the Saami and other residents in the county.

11. http://www.virke.no/talloganalyse/Documents/VirkeBygg\%20og\%20Anlegg\%20Rapport $\%$ 202013_Low.pdf

12. http://www.virke.no/talloganalyse/Documents/VirkeBygg\%20og\%20Anlegg\%20Rapport $\%$ 202013_Low.pdf

13. Manager, construction company.

14. Marketing Director, construction company.

15. http://www.tu.no/artikler/industri-japanerne-skriker-etter-ren-energi-na-vil-de-hente-den-frafinnmark/222173

\section{References}

Allen J. Lost Geographies of Power. Oxford: Blackwell, 2003.

Amin A., N. Thrift. Globalization, Institutions and Regional Development in Europe. Oxford: Oxford University Press, 1992.

Arbo, P., and B. Hersoug, eds. Oljevirksomhetens Inntog i Nord: Nceringsutvikling, Politikk og Samfunn. Oslo: Gyldendal Akademisk, 2010.

Asheim, B., and M.S. Gertler. “'The Geography of Innovation': Regional Innovation Systems.” In The Oxford Handbook of Innovation, eds. I.J. Fagerberg, D.C. Mowey, and R.R. Nelson, 291-317. Oxford: Oxford University Press, 2005.

Boschma, R., and K. Frenken. "Technological Relatedness and Regional Branching." In Beyond Territory. Dynamic Geographies of Knowledge Creation, Diffusion and Innovation eds. H. Bathelt, M.P. Feldman, and D.F. Kogler, 64-81. London: Routledge, 2011.

Coe N., M. Hess, H.W.-C. Yeung, P. Dicken, and J. Henderson. "Globalizing' Regional Development: A Global Production Networks Perspective". Transaction of the Institute of British Geographers 29(2004): 468-84.

Cooke P., M.G. Uranga, and G. Etxebarria. "Regional Innovation Systems: Institutional and Organizational Dimensions". Research Policy 26, no. 4-5 (1997): 475-91. 


\section{T. Nilsen and S. Karlstad}

Dawley S. "Creating New Paths? Offshore Wind, Policy Activism, and Peripheral Region Development". Economic Geography 90, no. 1 (2014): 91-112.

Eikeland S. Building a High North Growth Pole: The Northern Norwegian City of Hammerfest in the Wake of Developing the "Snow White" Barents Sea Gas field. Fournal of Rural and Community Development, no. 1 (2014): 57-71.

Eikeland, S., and T. Nilsen. "Local Content in Emerging Growth Poles: Local Effects of Multinational Corporations' Use of Contract Strategies.” Norwegian fournal of Geography 70, no. 1 (2016). Doi: http:// dx.doi.org/10.1080/00291951.2015.1108361.

Eikeland, S., T. Nilsen, and S. Karlstad. “Åpningen av Barentshavet: Skapes en ny nordlig vekstpol i den norske oljeøkonomiens nordlige periferi?” In Oljevirksomhetens inntog i nord: Nceringsutvikling, politikk og samfunn, eds. P. Arbo, and B. Hersoug, 147-69. Oslo: Gyldendal akademisk, 2010.

EWEA. European Wind Energy Association, (2007). Delivering offshore wind Power in Europe. Policy recommendations for large-scale deployment of offshore wind power in Europe by 2020. http://www.ewea. org/fileadmin/ewea_documents/images/publications/offshore_report/ewea-offshore_report.pdf.

Feldman, M.P. "Perspectives on Entrepreneurship and Cluster Formation: Biotechnology in the US Capitol Region." In The Economic Geography of Innovation, ed. K.P. Polenske, 241-60. Cambridge: Cambridge University Press, 2007.

Finnmaksloven. 2005. Lov om rettsforhold og forvaltning av grunn og naturressurser $i$ Finnmark fylke (finnmarksloven). https://lovdata.no/dokument/NL/lov/2005-06-17-85 (accessed May 32016 ).

Fitjar R. Region-building in the Arctic periphery: the discursive construction of a petroleum region. Geografiska Annaler: Series B, Human Geography 95, no. 1 (2013): 71-88.

Grabher, G. "Yet Another Turn? The Evolutionary Project in Economic Geography." Economic Geography 85 (2009): 119-27. Doi: 10111/j.1944-8287.2009.010.16x.

Halvorsen, K. Utfordringer for ncringslivet - hvor skal virkemiddelapparatet gå?. http://www.regjeringen.no/nb/ dokumentarkiv/Regjeringen-Bondevik-II/nhd/taler-og-artikler/2002/virkemiddelgjennomgangen-utfordringerfo.html?id=113073 (accessed August 5, 2015).

Hassink R. Regional Resilience: A Promising Concept to Explain Differences in Regional Adaptability?” Cambridge Journal of Regions. Economic and Society 3(2010): 45-58.

Henderson, J., P. Dicken, M. Hess, N. Coe, and H.W.-C. Yeung. "Global Production Networks and Economic Development." Review of International Political Economy 9 (2002): 436-64.

Isaksen A. "Innovation Dynamics of Global Competitive Regional Clusters: The Case of The Norwegian Centres of Expertise". Regional Studies 43, no. 9 (2009): 1155-66.

Isaksen, A., and M. Trippl. "New Path Development in the Periphery. Papers in Innovation Studies." Paper no. 2014/31, CIRCLE, Centre for Innovation, Research and Competence in the Learning Economy, Lund University, 2014.

Jacobs W., Lagendijk A. "Strategic Coupling as Capacity: How Seaports Connect to Global Flows of Containerized Transport". Global Networks 14, no. 1 (2014): 44-62.

Kogler D. "Editorial: Evolutionary Economic Geography - Theoretical and Empirical Progress". Regional Studies 49, no. 5 (2015): 705-11.

Leibovitz J. "Embryonic' Knowledge based Clusters and Cities: The Case of Biotechnology in Scotland". Urban Studies 41, no. 5/6 (2004): 1133-55.

MacKinnon, D., A. Cumbers, A. Pike, K. Birch, and R. McMaster. "Evolution in Economic Geography: Institutions, Political Economy and Adaption.” Economic Geography 85, no. 2 (2009): 129-50.

MacKinnon D. Beyond strategic coupling: Reassessing the firm-region nexus in global production networks. Fournal of Economic Geography 12(2011): 227-45.

Martin R. “( $\mathrm{Re})$ Placing Path Dependence. A response to the Debate”. International fournal of Urban and Regional Research 36, no. 1 (2012): 179-92.

Martin R., and P. Sunley. "Path Dependence and Regional Economic Evolution". Fournal of Economic Geography 64, no. 4 (2006): 395-437.

Ministry of Petroleum and Energy. (2010-2011). Meld. St. 28. En ncering for framtida - om petroleumsvirksomheten. Olje- og energidepartementet 1 . http://www.regjeringen.no/nb/dep/oed/dok/regpubl/stmeld/2010-2011/meld-st-28-2010-2011.html?id=649699 (accessed May 32016 ).

Morgan, K. "Path Dependence and the State." In Re-framing regional Development, ed. P. Cooke, 318-40. London: Routledge, 2013.

Narula R. "Innovation Systems and 'Inertia' in R\&D Location: Norwegian Firms and the Role of Systemic Lock-in”. Research Policy 31(2002): 795-816. 
Nilsen, T. Selskapsstrategier teller, forhandlinger avgjør. Regionale interesser i utbyggingsprosjektene Snøhvit og Ormen Lange. Avhandling for graden Ph.D., Det samfunnsvitenskapelige Fakultet, Universitetet i Tromsø, 2008.

Nilsen, T., I. Berg Nilssen and S. Karlstad. Norsk leverandørindustri sin konkurranseevne $i$ en globale offshorencering: Leveranser til Goliat-prosjektet $i$ Barentshavet. [Rapport] Norut Alta-report 2013:11. Alta: Norut Alta, 2013.

Nilssen, I., S. Karlstad, T. Nilsen, E. Angell, A. Hervik, B. Bergem, and L. Bræin. Erfaringsstudie om ringvirkninger fra petroleumsvirksomhet for nceringsliv og samfunn for øvrig: Kunnskapsinnhenting for det nordøstlige Norskehavet. Utarbeidet på oppdrag fra Olje- og Energidepartementet. Norut Alta-rapport 2012:08. Alta: Norut \& Molde: Møreforskning, 2012.

Rees, K. "Collaboration, Innovation and Regional Networks: Evidence from the Biotechnology Industry of Greater Vancouver.” In ed. A. Lagendijk and P. Onias, Proximity Distance and Diversity. Issues on Economic Interaction and Local Development, 191-215. Aldershot: Ashgate, 2005.

Sanches A.M. "Regional Innovation and Small High Technology Firms in Peripheral Regions". Small Business Economics 4(1992): 153-68.

Simmie J. "Path-Dependence and New Technological Path-Creation in the Danish Wind Power Industry". European Planning Studies 20, no. 5 (2012): 753-72.

Research Council. (2011). Delivering offshore wind Power in Europe. Policy recommendations for large-scale deployment of offshore wind power in Europe by $2020 \mathrm{http}: / / \mathrm{www}$. forskningsradet.no/servlet/Satellite? $\mathrm{c}=$ Nyhet\&cid $=1253969506633 \& \mathrm{p}=1226993846904 \&$ pagename $=$ renergi $\% 2 \mathrm{FHoved}$ sidemal $($ accessed May 3 2016).

Research Council. (2015). Indikatorrapporten 2015. http://www.forskningsradet.no/prognett-indikatorrapporten/ Indikatorrapporten_2015/1254007537710 (accessed May 3 2016).

Tödtling, F., and M. Trippl. "One Size Fitz all? Towards a Differentiated Regional Innovation Policy Approach." Research Policy 34 (2005): 1203-19.

Yeung H.W.-C. Regional Development and the Competitive Dynamics of Global Production Networks: An East Asian Perspective. Regional Studies 43(2009): 325-52. 